\title{
Constipation in children
}

\author{
Nadeem A Afzal ${ }^{1 *}$, Mark P Tighe $^{2}$ and Mike A Thomson ${ }^{3}$
}

\begin{abstract}
Constipation remains a frequent presentation to paediatricians, with significant health resource implications. We present a practical guide to the management of paediatric constipation and evaluate the current evidence for treatment regimens, to help the clinician in treating a condition that can be distressing and has a significant impact on affected families.
\end{abstract}

\section{Introduction}

Constipation is a very common presentation, both in primary and secondary care. Prevalence of functional constipation in children ranges from 4-36\% [1-3]. In the hospital setting, paediatric constipation forms $3 \%$ of all referrals to paediatric practice and up to $25 \%$ to paediatric gastroenterologists. In addition a recent American study suggests that there is a cost of health resources for children with constipation, estimated at $\$ 3.9$ billion/year [4].

This article aims to be a practical guide for paediatricians and primary care physicians, to outline the current diagnostic criteria and provide an evidence-base for the medical management of idiopathic constipation in children, in the light of recent National Institute of Clinical Excellence (NICE) guidelines on constipation [5]. With increased patient and parental understanding and support, as well as improving toileting habit, increasing fibre and optimising laxatives; the potential exists to deliver a significant benefit to children.

\section{Normal Bowel Habit in Children}

Considerable variation in 'normal' bowel habit in children is accepted. In a UK based study of 350 pre-school children (1-4 years of age), $96 \%$ of the children passed bowel motions between 3 times a day to alternate daily [6]. Stool frequency is also age-dependent. Nyhan, in a study of 800 babies described a peak frequency of 4.4 per day at 5 days of age [7], and may be as high as 13 per day in breast fed infants. Although a difference in stool frequency may exist between breast and bottle fed

\footnotetext{
* Correspondence: N.afzal@soton.ac.uk

'Paediatric Department, Southampton University Hospitals NHS Trust, Southampton General Hospital, Tremona Rd, Southampton, Hants, SO16 6YD, England

Full list of author information is available at the end of the article
}

babies, time to first stool after passage of meconium remains the same in both groups [8].

\section{Definition}

The wide variation in normal defaecation patterns in children discussed above makes it difficult to define constipation. Normal ranges also vary with age and place of residence [9].

Functional constipation has been defined by the ROME III classification [10] as 2 or more of the following features in a child with a developmental age of at least 4 years and occurring at least once per week for at least 2 months before diagnosis (with insufficient criteria for diagnosis of irritable bowel syndrome).

- 2 or fewer defaecations in the toilet per week

- At least 1 episode of faecal incontinence per week

- History of retentive posturing or excessive volitional stool retention

- History of painful or hard bowel movements

- Presence of a large faecal mass in the rectum

- History of large diameter stools that may obstruct the toilet

More recently, the term 'non-retentive faecal soiling' has been described for children soiling without difficult infrequent defaecation. PACCT (The Paris Consensus on Childhood Constipation Terminology Group) have defined this as passage of stools in an inappropriate place, occurring in children with a mental age of 4 years and older, with no evidence of constipation on history or examination [11]. The Iowa criteria of constipation in children $\geq 2$ years of age include two or more of the following during the previous 8 weeks:
Ciomed Central

(ㄷ) 2011 Afzal et al; licensee BioMed Central Ltd. This is an Open Access article distributed under the terms of the Creative Commons Attribution License (http://creativecommons.org/licenses/by/2.0), which permits unrestricted use, distribution, and reproduction in any medium, provided the original work is properly cited. 
$\geq 1$ episodes of faecal incontinence per week

Large stools in the rectum or felt on abdominal examination

Passing of stools so large that they obstruct the toilet Retentive posturing (withholding behaviour)

Painful defecation

$<3$ bowel movements per week.

How sensitive and specific are these definitions? In a recent Turkish study on 485 children being treated for constipation, 33 children $(6.8 \%)$ were not recognised by the Rome III criteria used in the study, due to problems with age restriction. 45 (9.2\%) children were not recognized using the PACCT criteria due to only having scybalous, pebble-like defaection pattern (rather than passing large stools obstructing the toilet). Only $60 \%$ had a defaecation pattern of less than 3 per week [12].

Given below are details of individual symptoms and their significance in relation to the definitions above.

\section{Symptoms of constipation}

\section{Infrequent stools}

Reduced bowel movement is commonly used to make a diagnosis. In a study of 178 children with constipation in Iowa, $58 \%$ had $<3$ bowel movements per week [9] and in another study $41.3 \%$ of children with symptoms of constipation were found to have infrequent stools [13]. Children $<2$ years of age had constipation with symptoms of passage of hard or pebble-like stools with straining, withholding or painful defaecation. The diagnosis would be missed in $50 \%$ if infrequent stools were the only criteria used for diagnosis.

\section{Pain}

Children may present with pain in the abdomen or during defaecation. Non-specific abdominal pain has been reported in $33 \%$ of children with constipation in one study. Painful defaecation occurs when children complain of pain or scream during or on anticipation of stools, observed in up to $68 \%$ of children with constipation [9]. They may pass blood with stools (see below).

\section{Soiling}

Faecal incontinence has been associated with 'constipation' in up to $90 \%$ [13]. Soiling is involuntary, often small and stains the underwear, however if larger in amount can be mistaken for diarrhoea. Medications may be incorrectly reduced which may instead need to be maintained or increased.

\section{Stool withholding manoeuvres}

This may be misinterpreted as straining. In infants backarching, and in older infants/toddlers, standing on toes, extending legs or rocking back and forth preventing anal relaxation are typical features. Some children may hide in a corner standing stiffly or squatting.

\section{Blood in stools}

Fissures may result in bleeding and painful defaecation in older children. Children may present with blood on tissue paper after wiping. Perineal examination should include looking for infection/cellulitis, fissures, fistulae or tags. The latter, associated with faltering growth or delayed puberty, may be suggestive of Crohn's disease. Comparatively children with polyps commonly present with painless bleeding. Rectal bleeding in infancy is often associated with cow's milk protein allergy rather than constipation [14].

\section{Enuresis and other urinary symptoms}

Urinary symptoms have been reported in 9-13\% of children with a diagnosis of constipation, and urinary incontinence $10.5 \%$, and it has been implicated in the pathoaetiology of enuresis [13]. Asymptomatic constipation may exacerbate urinary symptoms in children with enuresis [15]. The impacted stool in the rectum compresses the bladder, reduces its functional capacity, and provokes earlier sensation to void. In addition, chronic pelvic floor spasm prevents complete relaxation during voiding, and contributes to postvoid residuals [16-18].

\section{Associations}

1. Obesity $[19,20]$

Overall a higher incidence of obesity has been found in constipated children, compared to the general paediatric population, with associated psychosocial issues, poor diet, low activity levels, and compliance problems.

2. Poor Fluid intake

Optimal fluid intake is recommended by NICE as a necessary adjunct in the management of constipation [5]. However, excessive fluid intake can result in reduction in eating/fibre, which may be counter-productive [21].

\section{Epidemiology}

A positive family history has been found in $28-50 \%$ of constipated children and a higher incidence reported in monozygotic than dizygotic twins [22]. Constipation tends to be equal in both sexes below 5 years, commoner in girls above 13 years of age, and peak incidence is at the time of toilet training around 2-3 years of age [23].

\section{Aetiology of idiopathic constipation}

Understanding the trigger for constipation in children is important. This may occur secondary to inadequate 
evacuation as a result of rushing to school in the morning, quick use of the school toilet, the child withholding stools as they may be occupied by something of greater interest. Occasionally children may have had a hard stool due to decreased fluid intake after a febrile illness or during a holiday trip.

Children with difficult toilet training are more likely to be constipated. These children may be less adaptable and negative in mood. $74 \%$ would hide stool and $37 \%$ would ask for pull ups to leave the stool in it [24]. These children benefit more from constant encouragement using star charts/other reward techniques, rather than confrontation (see below).

Secondary constipation, for instance due to hypothyroidism, Hirschsprung's disease, or changes in calcium levels is rare and accounts for less than $10 \%$ of cases. However cow's milk protein allergy, particularly non-IgE mediated, with associated colonic dysmotility may manifest as secondary constipation $[25,26]$, with one study estimating its prevalence in up to $40 \%$ of refractory constipation [27].

Up to $63 \%$ of children with constipation and faecal soiling will have a history of painful defaecation beginning before 3 years of age and secondary withholding behaviour $[28,29]$. Stool with-holding follows passing a hard painful bowel motion, creating a vicious cycle of pain leading to further withholding, stool hardening and increase in size with subsequent megarectum, lack of defaecatory signal etc. Parents may mistake such withholding behaviour as straining.

\section{Diagnosis}

Constipation is diagnosed by clinical history and examination. History should include a detailed exploration of symptoms, looking at potential precipitants, and for 'red flags' to exclude organic pathology (see table 1). A physical examination should include an abdominal examination to assess the degree of faecal loading, as well as neurological assessment of the spine and lower limbs.

Table 1 Red Flags: Common symptoms and signs to suggest organic causes of constipation

\begin{tabular}{ll}
\hline History & Examination \\
\hline Failure to thrive & $\begin{array}{l}\text { Absent/Brisk lower limb } \\
\text { reflexes }\end{array}$ \\
\hline Delayed passage of meconium & Mouth ulcers \\
\hline Abnormal bowel habit since birth & $\begin{array}{l}\text { Blood/mucus mixed in } \\
\text { with stool }\end{array}$ \\
\hline $\begin{array}{l}\text { Sensitivity to cold, fatigue, dry skin, } \\
\text { pallor }\end{array}$ & $\begin{array}{l}\text { Perianal skin tags or } \\
\text { fistulae }\end{array}$ \\
\hline $\begin{array}{l}\text { Change of bowels with introduction of } \\
\text { cow's milk }\end{array}$ & \begin{tabular}{l} 
Associated hypotonia \\
\hline Weight loss
\end{tabular} \\
\hline
\end{tabular}

Perineal examination helps to look for perianal cellulitis and anorectal anomalies. There is now clear NICE guidance on rectal examinations in children that these should only be performed by healthcare professionals who are competent in recognising anorectal anatomical problems and Hirschsprung's disease, and this examination can provide useful information on sphincter tone, and rectal loading. Constipation should be considered as a differential diagnosis in all children presenting with abdominal pain [30]. In a child with an underlying neurological diagnosis or developmental delay, irritability may be suggestive; and a high index of suspicion maintained, as constipation may be present in the context of gut dysmotility. Constipation may be missed in $1 / 3^{\text {rd }}$ of children with autism if clinical criteria alone are used to make a diagnosis [31]. Other considerations include an association between children with refractory constipation and abuse but features such as soiling should be placed into context and are not discriminatory in isolation [32].

It is important to watch for growth failure, 'overflow diarrhoea' with blood and/or mucus, pallor or fatigue, or failure to respond to conventional treatment during the course of management, and be prepared to re-evaluate. Children with inflammatory bowel conditions (with or without anal involvement) and coeliac disease may present with constipation. It is important to remember that like fever, constipation may be a symptom and not a diagnosis.

Finally, even in idiopathic constipation, it is useful to understand the underlying mechanics and family dynamics, which, if not addressed, may often lead to failure of intensive laxative treatment.

\section{Investigations}

Often tests are not needed and only conducted to exclude secondary constipation. A nutritional assessment may be part of the initial blood screen which includes screening for thyroid and coeliac disease [5]. In children with constipation specific IgE to cow's milk is not diagnostic of cow's milk allergy $[25 ; 26]$.

\section{Plain abdominal $\mathrm{X}$ ray}

Constipation is a clinical and not a radiological diagnosis. Occasionally a plain abdominal $\times$ ray is useful in cases of diagnostic uncertainty, but remains highly subjective. Scoring systems have been trialled to improve consistency. One system, the Leech system [33] divides the abdominal $\times$ ray into three sections, ascending colon and proximal transverse colon; distal transverse colon; descending colon and rectosigmoid area. Each segment is then assessed for the presence of stools (score 0-5 where 0 indicates no stool; 5 means gross faecal loading with bowel dilation). The Leech system has been shown 
to be superior to two other systems (Barr and Blethyn) by two paediatric radiologists for validity (kappa values of 0.88 and $1.00, \mathrm{P}<0.05$ ) [34]. In another study X-rays were comparatively scored by a student, junior doctor and consultant. The results suggested that scoring by these systems is dependent on the experience of the observer, and does not accurately discriminate between constipated children and children without constipation [35].

Presence of firm, packed hard stool in the rectum correlates closely with radiological evidence of faecal retention, with sensitivity and positive predictive values exceeding 90\% [33,36,37].

A 'Shapes' bowel transit study, where a patient ingests three different radio-opaque marker shapes on consecutive days and a subsequent $\times$ ray on day 4 identifies where these markers are, can be very helpful in determining specific anatomical area of hold up. For instance recto-sigmoid accretion of markers would be observed in long-standing constipation of idiopathic origin, such as with stool withholding, whereas markers may be distributed more widely throughout a dysmotile colon.

\section{Ultrasound}

Bijoś has described using ultrasound (USS) for diagnosis of constipation [38]. The transverse diameter of the rectal ampulla increases with age and thus influenced the USS measurements in both the patient and control groups. The numerical values of this parameter differed significantly between patients and controls in all age groups. The rectopelvic ratio is the ratio of the width of the rectal ampulla (on USS) to the distance between the anterior superior iliac spines (measured externally using a measuring tape) and has been used to define 'megarectum'.

\section{Anorectal/Colonic Manometry}

This is not a first line investigation but has been used in children with refractory symptoms, often with failed multiple treatments, who may have had required multiple hospitalisations for treatment of their symptoms. Presence and normal propagation of high amplitude propagating contractions (HAPCs) with presence of a gastro-colonic response is suggestive of intact neuromuscular function. The highest prevalence of motor abnormalities have been reported in children with intestinal pseudo-obstruction [39]. Colonic manometry can be useful for planning surgical intervention in children with refractory symptoms.

\section{Rectal biopsy}

Deep suction rectal biopsy is the gold standard for diagnosing Hirschsprung's disease. If the age at onset of constipation is after the neonatal period, Hirschsprung's disease is very unlikely [40]. Ultra short Hirschsprung's disease is rare, and was first described by Davidson and Bauer in 1958 [41]. Strip biopsies are recommended to avoid falsely negative biopsies. Strip biopsies include mucosa from the dentate line to the rectum, and a full thickness biopsy is preferable.

\section{Management}

The practicing physician should be up to date with the principles of management. Recently published data from Virginia (USA) suggested that up to $86 \%$ of the primary care physicians had no awareness of the published clinical guidelines for constipation in children [42]. After 2 months of treatment, nearly $40 \%$ of children remained symptomatic; which was improved by improved parental understanding and regular laxatives [43].

\section{Education}

Parental/family education regarding their understanding of the aetiology, symptoms and principles of management remain critical in achieving success. Management starts with explaining the physiological basis of constipation and soiling to the child and family. NICE recommend that the child should never be blamed for soiling and this should be explained to parents [5].

The family should be encouraged to adhere to the treatment plan (both medication and a regular toileting pattern) with emphasis on its efficacy for long-term symptom improvement. Underlying psychosocial problems should be considered in the first meeting. These may range from bullying to pressure to use a single family toilet quickly. Clear and simple messages should be given to avoid overwhelming the family.

Toileting at school may need to be addressed with the teacher with involvement of the school nurse. Boyt [44] in a postal questionnaire in Iowa, described lack of awareness of most teachers regarding childhood constipation. One third of respondents indicated that they ask children to wait to go to the bathroom. Suboptimal conditions existed in most school toilets, with only $35 \%$ of the boys' toilets and $48 \%$ of the girls' toilets reported as "always clean".

\section{Diet}

NICE recommend optimising fibre intake [5,45-47]. Children with normal defaecation patterns in comparison to children with constipation have better fibre intake. A strong family history of cow's milk protein intolerance, or raised eosinophil count, and elevated specific IgE to cow's milk, would merit a trial of cow's milk protein-free diet, and in infants, a hydrolysed formula [26]. A trial of cow's milk protein-free diet is also merited for non-IgE-mediated cow's milk protein intolerance, in those with a suggestive history, for example if 
constipation started on switching from breast- to formula-feeding [48], or in those with refractory constipation [25]. Increased fluid intake is recommended [5;49], but not at the expense of excessively restricting calorie intake in younger children.

\section{Evidence base for medications used in treatment of constipation in children}

\section{Search criteria}

We searched PubMed, Medline, and Embase and then hand search reviews from the past 5 years for 'constipation', 'soiling', 'faecal', 'fecal', 'incontinence', 'child\$', 'infant', 'baby', 'drugs', 'therapy' and 'treatment'. Reviews and abstracts are excluded. We appraised the original clinical trials using the Levels of Evidence adopted by the Oxford Centre for Evidence-based Medicine, and produced evidence-based recommendations [50]. We have constructed a flow chart, showing the outcome of the search, the number of excluded papers by reason for exclusion and number of papers selected for review (Figure 1).

\section{Disimpaction}

Disimpaction is important, particularly in severe cases, for maintenance treatment to work, according to NICE [5]. An escalating dose of polyethylene Glycol (PEG) is recommended as first-line treatment (see evidence below) with a stimulant added if required. The family should be prepared for potential worsening of overflow soiling initially. An excessive dose of stimulant risks precipitating acute abdominal pain in cases of impaction. If possible, such treatments should commence during weekends/holidays to minimise stress for the child and

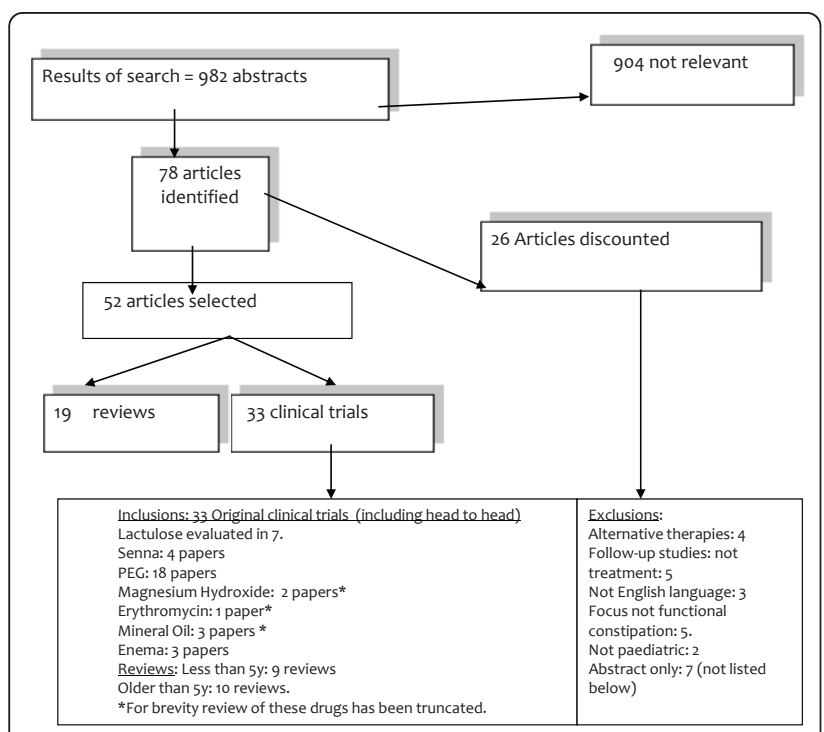

Figure 1 Flow Chart family. Diarrhoea in a constipated child initialising a treatment is likely to represent spurious overflow diarrhoea and the treatment would need to be increased or at least maintained rather than reduced. It is sensible to review the child regularly. In practical terms, this may mean 2-3 appointments 1-2 weeks apart initially. Specialist nurses can play a major role during this period. Disimpaction should generally be initiated orally; further discussion of enemas is outlined below.

\section{Maintenance therapy}

Once disimpaction has taken place, the aim of laxative treatment, as recommended by NICE, should be to keep the child, symptom free with regular soft bowel actions and should be commenced immediately [5], initially at half the dose required for disimpaction. PEG is the first line treatment, with a stimulant laxative such as senna added if required, or substituted if PEG is not tolerated. During this period, the child should be encouraged to use the toilet regularly, particularly 15-30 minutes after meals. A useful rule of thumb is to aim for 1-2 soft stools a day, though this is not definitive. Laxative treatment needs to be tailored to the child; and toilet training can often be as important as the choice of laxatives. Give parents the support to allow them to vary the laxative dose in response to their child's symptoms (for example through telephone advice from a specialist nurse). Once improvement is seen, laxatives should be gradually reduced and never stopped suddenly. Improvement in chronic cases may take place over months and can take years in some cases. Reinforcement of the management plan may be required. Relapses are common and may need to be treated with increasing doses of laxatives. A reward system with star chart is often used with success. Finally, toilet training should be postponed in a constipated 2-year old until after disimpaction.

Choice of laxatives may vary between regions and countries. Lactulose, macrogols, and Senna (table 2, 3, 4) are popularly used treatments in the UK. In the section below we have looked at the available evidence of efficacy of these medications, with an abbreviated discussion of mineral oil, erythromycin and magnesium hydroxide (due to the paucity of evidence). The evidence base for enemas (table 5) is also reviewed.

\section{Lactulose (see table 2) [51-56] \\ Summary}

Older case series of variable quality point to some benefit. However RCTs have shown either inferiority to PEG (Voskuijl et al, Dupont et al) or absence of benefit (von Ginkel, Gremse et al).

\section{Conclusions}

Evidence points to a lack of benefit from lactulose, but more studies are needed (Grade B). 
Table 2 Lactulose

\begin{tabular}{|c|c|c|}
\hline Authors & $\begin{array}{l}\text { Study Group+ } \\
\text { type }\end{array}$ & Methods + Key Outcomes \\
\hline $\begin{array}{l}\text { Voskuijl et al (2004) } \\
\text { [51] }\end{array}$ & $\begin{array}{l}100 \text { patients } \\
\text { Study type : } 1 \mathrm{~b}\end{array}$ & $\begin{array}{l}\text { Methods: } 8 \text { wk double blinded, multi-centre RCT: PEG } 3350 \text { vs lactulose. } \\
\text { Results: Success greater for PEG group (56\%) vs. lactulose group (29\%) (less pain/straining). PEG significantly } \\
\text { less palatable }\end{array}$ \\
\hline Van Ginkel (2000) [52] & $\begin{array}{l}48 \text { children } \\
\text { Study type :2b }\end{array}$ & $\begin{array}{l}\text { Methods: RCT: Biofeedback+ lactulose vs. biofeedback for } 7 \text { weeksResults: Both groups had improved } \\
\text { encopresis (group } 2 \text { significantly better (86\%) than group } 1 \text { (53\%) } \frac{p(0.01)}{p}\end{array}$ \\
\hline $\begin{array}{l}\text { Gremse et al (2002) } \\
\text { [59] }\end{array}$ & $\begin{array}{l}44 \text { children } \\
\text { Study type :1b }\end{array}$ & $\begin{array}{l}\text { Methods: Unblinded Crossover RCT Lactulose vs PEG 3350: } 2 \text { weeks } \\
\text { Results: Lactulose had a significantly longer mean transit time compared to PEG } 3350 \text { (55.3 vs. } 47.6 \text { hrs, } \\
p=0.038 \text { ). Stool form, frequency, and ease of passage were similar for each laxative. }\end{array}$ \\
\hline Perkin (1977) [53] & $\begin{array}{l}21 \text { children } \\
\text { Study type : } 2 b\end{array}$ & $\begin{array}{l}\text { Methods: Randomised unblinded crossover study lactulose vs senna:3 weeks Results: Lactulose more likely } \\
\text { to give greater number of days when normal stools were passed }(p<0.01) \text {. Side-effects significantly higher } \\
\text { ( } p<0.001) \text { for senna. }\end{array}$ \\
\hline $\begin{array}{l}\text { Dupont et al (2005) } \\
\text { [54] }\end{array}$ & $\begin{array}{l}96 \text { children } \\
\text { Study type :2b }\end{array}$ & $\begin{array}{l}\text { Method: Random allocation, open label cohort study } \\
\text { Results: More than } 90 \% \text { of children recovered normal bowel habits. Faecal mass in the rectum and } \\
\text { abdominal pain were markedly reduced and appetite improved. }\end{array}$ \\
\hline $\begin{array}{l}\text { Keuzen-kamp et al } \\
\text { (1996) [55] }\end{array}$ & $\begin{array}{l}244 \text { patients } \\
\text { Study type :4 }\end{array}$ & $\begin{array}{l}\text { Methods: Case series over } 25 y \text { : median follow up of } 4 \text { years } \\
\text { phases: 1) evacuation with lactulose/bisacodyl } \\
\text { 2)maintenance: regular toileting + wean laxatives to ensure soft stools daily } \\
\text { 3) introduce high fibre diet +wean laxatives. } \\
\text { Results: } 66 \% \text { cured, } 34 \% \text { still symptomatic, } 12 \text { had persistent symptoms. Of all } 39 \% \text { had at least one } \\
\text { recurrence. }\end{array}$ \\
\hline $\begin{array}{l}\text { Connolly et al (1974) } \\
\text { [56] }\end{array}$ & $\begin{array}{l}164 \text { patients } \\
\text { Study type :4 }\end{array}$ & $\begin{array}{l}\text { Methods: Open-label cross-over study: lactulose vs. irritant laxatives: (Senna/bisacodyl) } 7 \text { days } \\
\text { Results: } 58 \% \text { of lactulose group vs } 42 \% \text { of stimulant group had normal stool. }\end{array}$ \\
\hline
\end{tabular}

\section{Polyethylene Glycol (see table 3) [51,54,57-70] Summary}

Certainly PEG is now recommended as first line treatment as per UK NICE guidelines [5]. The studies cover the different scenarios of treatment: oral resolution of impaction and maintenance therapy for relief of constipation. Both PEG +E and PEG 3350 were evaluated. The largest studies (Thomson et al, Candy et al, Dupont et al, Youssef et al) demonstrate efficacy in resolution of symptoms from chronic constipation. Candy et al $\left(2^{\text {nd }}\right.$ phase of study) found that PEG gave greater stool frequency and had less adverse effects than lactulose. Michail et al evaluated the dose range for children $<18$ $\mathrm{m}$ and found that a safe and effective dose was $0.78 \mathrm{~g} /$ $\mathrm{kg} /$ day. Loening-Baucke et al and Pashankar et al found a similar dose was safe and effective for older children over a mean period of over 8 months.

\section{Conclusions}

PEG is safe and effective in the treatment of impaction and chronic constipation. (grade B)

\section{Senna: (see table 4) $[53,56,71,72]$ Summary}

4 low-quality studies provide little evidence of benefit from Senna. Sondheimer et al found that mineral oil (compared to senna) was more likely to reduce the frequency of soiling and recurrence of symptoms of constipation. Perkin found that lactulose was significantly more likely to give greater number of days of normal stool motions compared to senna. Berg compared senna to placebo and found no significant differences in the number of soiling episodes per week. UK NICE guidance recommends stimulant use second line to PEG solutions [5].

\section{Conclusions}

Based on current evidence there is no benefit seen from senna, although no high-quality trials exist to date. (Grade D)

\section{Enemas: (see table 5) $[9,43,56]$ \\ Summary}

Enemas in these case series were used to relieve impaction prior to initiation of maintenance therapy. The authors would recommend a RCT comparing enema vs. no enema relief of faecal impaction to further assess the impact enemas have, both in the acute management and in the medium to long-term.

\section{Conclusion}

More evidence is needed to assess the role of enemas in impaction. (Grade D).

\section{Erythromycin}

1 study of 14 children showed some significant results: Further evaluation through RCTs is needed to assess erythromycin as an adjunct in chronic constipation [73].

\section{Magnesium hydroxide}

1 paper showed magnesium hydroxide inferior to PEG [60]. More evidence is needed to evaluate the role of magnesium hydroxide in constipation (grade D)

\section{Mineral Oil}

3 papers were identified. Gleghorn et al [74] showed that mineral oil was effective in treating impaction in children, and Tolia [75] showed that whilst mineral oil 
Table 3 Macrogols (Polyethylene Glycol)

\begin{tabular}{|c|c|c|}
\hline \multicolumn{3}{|l|}{ PEG 4000} \\
\hline Authors & $\begin{array}{l}\text { Study Group } \\
\text { Study type }\end{array}$ & Methods+Key Outcomes \\
\hline $\begin{array}{l}\text { Thomson et al (2007) } \\
\text { [57] }\end{array}$ & $\begin{array}{l}51 \text { children } \\
\text { Study type: 1b }\end{array}$ & $\begin{array}{l}\text { Methods: Double-blind crossover RCT PEG+E or placebo for } 2 \text { weeks } \\
\text { Results: Mean number of defaecations higher for PEG+E group vs placebo }(p<0.001) \text {. Also PEG }+E \\
\text { reduced pain on defaecation }(p=0.041) \text {, straining on defaecation }(p<0.001) \text {, stool consistency }(p< \\
0.001) \text { and percentage of hard stools }(p=0.001) \text {. Adverse events were all mild or moderate and were } \\
\text { similar for those children on PEG }+E \text { and placebo. }\end{array}$ \\
\hline Candy et al (2006) [58] & $\begin{array}{l}63 \text { children } \\
\text { Study type: } 2 b\end{array}$ & $\begin{array}{l}\text { Methods: Initial open cohort study of PEG+E (disimpaction) then double-blind RCT of PEG+E (Movicol) } \\
\text { vs. lactulose (maintenance) } \\
\text { Results: Disimpaction) successful in } 92 \% \text { children. Maximum dose }=4 \text { sachets }-4 \text { yr old) or } 6 \text { sachets } \\
\text { (5-11 yr olds); median time to disimpaction was } 6 \text { days. } \\
\text { Maintenance: Greater mean stool frequency in PEG +E group }(p=0.007) \text {. }\end{array}$ \\
\hline
\end{tabular}

\section{PEG 3350}

Gremse et al (2002) [59] Study described in the 'Lactulose section' - table

Loening-Baucke et al 79 children Methods: Double blind RCT PEG 3350 vs. magnesium hydroxide

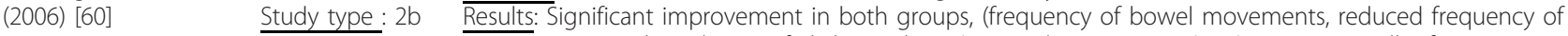
incontinence, and resolution of abdominal pain). Compliance $=95 \%$ (PEG) vs. $65 \%=$ milk of magnesia. At 12 months, $62 \%$ of PEG-treated children and $43 \%$ of MoM-treated children improving:

Youssef et al (2002) 40 children $\quad$ Methods: Prospective double-blind, parallel RCT 4 doses of PEG 3350

[61] Study type: 1b Results: Disimpaction in $75 \%$ of children overall but significant difference between two higher doses vs. lower doses $(95 \%$ vs. 55\%, $\mathrm{P}<.005)$. All groups had an increased number of bowel movements during the 5 -day study versus baseline.

\begin{tabular}{|c|c|c|}
\hline $\begin{array}{l}\text { Michail et al } \\
\text { (2004) [62] }\end{array}$ & 28 patients & $\begin{array}{l}\text { Method: Cohort study with PEG. Mean duration } 6 \text { months } \\
\text { Results: Mean effective maintenance dose was } 0.78 \mathrm{~g} / \mathrm{kg} / \text { day. PEG relieved constipation in } 97.6 \% \text { of } \\
\text { patients. }\end{array}$ \\
\hline
\end{tabular}

Voskuijl et al (2004) [51] Study described in the 'Lactulose section' - table

Ingebo (1988) [63] 24 patients $\quad$ Methods: Case series: PEG+E given at 14-40ml/kg/hr until clear fluid obtained.

Study type : $4 \quad$ Results: children with encopresis required an average of $11 \mathrm{~L}$ over $22 \mathrm{~h}$. PEG+E successful in all children, and was safe.

Miller et al (2007) [64] 121 patients Methods: Case series: single-site: All children over 6 month period diagnosed with 'constipation' from an

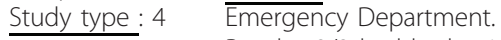

Results: 2/3 had had pain for less than 1 week. 70\% received an AXR. 1/3 received an enema in the ED. 74\% received laxatives on discharge (80\% given PEG). At follow-up, 35\% were using laxatives, and 27\% had sought additional care.

After an enema, 28\% discharged without laxatives.

\begin{tabular}{|c|c|c|}
\hline $\begin{array}{l}\text { Pashankar et al (2003) } \\
\text { [66] }\end{array}$ & $\begin{array}{l}83 \text { children } \\
\text { Study type : } 2 b\end{array}$ & $\begin{array}{l}\text { Methods: Cohort study for at least } 3 \mathrm{~m} \text { PEG given at } 0.8 \mathrm{~g} / \mathrm{kg} / \mathrm{day} \text { then adjusted to give } 2 \text { soft painless } \\
\text { stools/day } \\
\text { Results: Mean duration }=8.7 \text { months. Mean PEG dose was } 0.75 \mathrm{~g} / \mathrm{kg} \text { daily. No major adverse effects. All } \\
\text { children preferred PEG to other laxatives, Good daily compliance in } 90 \% \text { of children }\end{array}$ \\
\hline $\begin{array}{l}\text { Pashankar et al (2003) } \\
\text { [65] }\end{array}$ & $\begin{array}{l}74 \text { children } \\
\text { Study type :4 }\end{array}$ & $\begin{array}{l}\text { Methods: Case series: All given PEG } 3350 \text { for }>3 \text { months. } \\
\text { Results: mean duration of PEG therapy }=8.4 \mathrm{~m}(3-30 \mathrm{~m}) \text {. Weekly stool frequency, stool consistency, and } \\
\text { soiling improved significantly with PEG therapy in all patients. }\end{array}$ \\
\hline $\begin{array}{l}\text { Pashankar et al (2001) } \\
\text { [67] }\end{array}$ & $\begin{array}{l}24 \text { children } \\
\text { Study type : } 4\end{array}$ & $\begin{array}{l}\text { Cohort study: PEG for } 8 \text { weeks starting at } 1 \mathrm{~g} / \mathrm{kg} / \mathrm{d} \text { : adjusted every } 3 \text { days aiming: } 2 \text { soft stools } / \mathrm{d} \text {. } \\
\text { Results: Weekly stool frequency increased from } 2.3 \text { to } 16.9(\mathrm{p}<.0001) \text { with treatment. Stool consistency } \\
\text { improved }(\mathrm{p}<.0001) \text {. Mean effective dose was } 0.84 \mathrm{~g} / \mathrm{kg} / \mathrm{d} \text { (range, } 0.27-1.42 \mathrm{~g} / \mathrm{kg} / \mathrm{d} \text { ) }\end{array}$ \\
\hline Erickson (2003) [68] & $\begin{array}{l}46 \text { patients } \\
\text { Study type : } 4\end{array}$ & $\begin{array}{l}\text { Method: Retrospective review of PEG 3350, aiming for } 2 \text { soft stools a day. } \\
\text { Results: } \text { PEG caused significant increase in frequency of bowel movements }(p=0.0001 \text { ). Average final } \\
\text { dose was } 0.63 \mathrm{gm} / \mathrm{kg} \text {. Diarrhoea in } 9 \text { patients. } 18 \text { became dry, } 26 \text { had decreased wetting ( } 2 \text { no } \\
\text { improvement). }\end{array}$ \\
\hline Hanson (2006) [69] & $\begin{array}{l}23 \text { children } \\
\text { Study type : } 4\end{array}$ & $\begin{array}{l}\text { Method: Case series: } 7 \text { day disimpaction then maintenance PEG. } \\
\text { Results: } 23 \text { questioned on their children's experiences. } 96 \% \text { 'more than happy' with PEG+E. Prior to PEG } \\
+ \text { E treatment, } 57 \text { per cent of children were admitted to hospital and } 26 \text { per cent required home visits } \\
\text { for constipation treatment. After treatment, no child visited hospital/needed home visit. }\end{array}$ \\
\hline $\begin{array}{l}\text { Loening-Baucke et al } \\
\text { (2004) [70] }\end{array}$ & $\begin{array}{l}75 \text { constipated } \\
\text { children } \\
<2 \text { years } \\
\text { Study type: } 4\end{array}$ & $\begin{array}{l}\text { Method: Retrospective case series: PEG. } \\
\text { Results: Mean effective short-term PEG dose was } 1.1 \mathrm{~g} / \mathrm{kg} / \text { day and the mean long-term dose was } \\
0.8 \mathrm{~g} / \mathrm{kg} / \text { day. Constipation was relieved in } 85 \% \text { with short-term and in } 91 \% \text { with long-term PEG therapy. }\end{array}$ \\
\hline
\end{tabular}


Table 4 Senna

\begin{tabular}{|c|c|c|}
\hline Authors & Study Group+ type & Methods+ Key Outcomes \\
\hline Berg (1983) [71] & $\begin{array}{l}44 \text { children with soiling } \\
\text { (mean age } 7.9 \text { years) } \\
\text { Study type } 2 b \\
\text { All given toileting advice. }\end{array}$ & $\begin{array}{l}\text { RCT: senna vs. placebo vs. no treatment. } \\
\text { Results: All groups improved from baseline }(p<0.05) \text {. Senna no more effective than placebo/no } \\
\text { treatment. }\end{array}$ \\
\hline \multicolumn{3}{|c|}{ Perkin (1977) [53]- Study described in the 'Lactulose section' - table } \\
\hline $\begin{array}{l}\text { Sondheimer et al } \\
\text { (1982) [72] }\end{array}$ & $\begin{array}{l}37 \text { children } \\
\text { Study type: } 2 b\end{array}$ & $\begin{array}{l}\text { Methods: Non-blinded RCT Senna vs. mineral oil for } 3 \text { months } \\
\text { Results: Faecal soiling }+ \text { decreased stool frequency) significantly better in mineral-oil group. At } \\
\text { least } 1 \text { recurrence of symptoms occurred in } 66 \% \text { of mineral-oil-treated and } 89 \% \text { of Senna-treated } \\
\text { patients. }\end{array}$ \\
\hline
\end{tabular}

may be better tolerated, PEG may be more effective. Sondheimer in a non-blinded study showed mineral oil to be superior to Senna in reducing constipation recurrences when used over 3 months [72]. More evidence is needed to assess the role of mineral oil in treating constipation (Grade D).

\section{Management of difficult/refractory constipation}

Initial history and examination should be undertaken at the first appointment to exclude an organic aetiology and active investigations (as mentioned before) should be undertaken. If these reveal evidence of slow colonic transit, this may suggest a neuronal disorder of the intestine, which may require colonic manometry and a full thickness biopsy for definitive diagnosis.

As discussed earlier, continued extraneous factors such as bullying, adverse family dynamics and child abuse should be considered. Equally, children with neurological/psychiatric conditions may find it difficult to learn/adhere to a toileting routine. Negotiated and nonpunitive behavioural interventions in conjunction with medicinal and dietary treatment is recommended by NICE guidance [5]. A period of inpatient admission may be useful. This can be aided by a multi-disciplinary team, including nurses experienced in managing children with constipation. Psychologists and play therapists can introduce methods of relaxation for toileting and dieticians can also input into fluid intake and fibre content.
Surgery should only be considered for appropriate organic indications or if medical management at a tertiary level fails, and is beyond the scope of this article.

\section{Prognosis}

A high proportion of relapses have been reported after success in the initial treatment. These relapses have been reported to be commoner in boys than girls [76]. However the prognosis for constipation in under fives is excellent, with constipation resolving in $88 \%$ of children in this age group, when followed over an eighteenmonth period. The non-responders came from families with increased degree of psychosocial problems where reduced compliance of medications was suspected [77]. In general $50 \%$ of children with chronic constipation will be cured after a year and $65-70 \%$ after 2 years, with much higher rates in motivated, adherent families [78]. Two studies show $34-37 \%$ to be still constipated 3-12 years after start of treatment $[9,55]$.

\section{Conclusion}

In this article we have outlined the current trends in the assessment and treatment of constipation and reviewed the current evidence-base for the therapies currently in wide use, within the context of recent NICE guidance. Constipation remains a prevalent problem, which can have a huge impact on children's quality of life, and places a burden on primary and secondary care. With increased patient and parental understanding and

Table 5 Enemas

\begin{tabular}{|c|c|c|}
\hline Authors & $\begin{array}{l}\text { Study Group } \\
\text { Study type }\end{array}$ & Methods+ Key Outcomes \\
\hline Loening-Baucke (1993) [9] & $\begin{array}{l}174 \text { children } \\
\text { Study type: } 4\end{array}$ & $\begin{array}{l}\text { Methods: case series: Long-term follow-up questionnaire. All given education, enemas for } \\
\text { disimpaction, and dietary fibre+ magnesium hydroxide. } \\
\text { Results: On presentation } 64 \% \text { impacted +received enema. } 57 / 90 \text { (63\%) had recovered. } 17 \text { (19\%) still } \\
\text { required laxatives, and } 16(18 \%) \text { still soiling regularly. }\end{array}$ \\
\hline Borowitz et al (2005) [43] & $\begin{array}{l}119 \text { children } \\
\text { Study type: } 4\end{array}$ & $\begin{array}{l}\text { Methods: Case series: Follow-up: Colonic evacuation then magnesium hydroxide }(77 \%) \text {, senna syrup } \\
(23 \%), \text { mineral oil }(8 \%) \text {, and lactulose }(8 \%) \\
\text { Results: Children who underwent some form of colonic evacuation followed by daily laxative therapy } \\
\text { were more likely to have responded to treatment }(p<0.05) \text {. }\end{array}$ \\
\hline Miller et al (2007) [64] & See PEG sect & \\
\hline
\end{tabular}


support, as well as improving toileting habit, increasing fibre and optimising laxatives; the potential exists to deliver a significant benefit to children, and revolutionise what can otherwise be an intractable and distressing condition.

\section{Author details}

'Paediatric Department, Southampton University Hospitals NHS Trust, Southampton General Hospital, Tremona Rd, Southampton, Hants, SO16 6YD, England. ${ }^{2}$ Paediatric Department, Poole Hospital NHS Trust, Longfleet Rd, Poole, BH15 2JB, England. 'ㄹepartment of Paediatric Gastroenterology, The Sheffield Children's NHS Trust, Western Bank, Sheffield, S10 2TH, England.

\section{Authors' contributions}

MAT and NAA conceived the article. MPT performed and wrote the literature search, and NAA wrote the article. MPT and NAA edited the article for publication. All authors have read and approved the script

\section{Competing interests}

The authors declare that they have no competing interests.

Received: 30 December 2010 Accepted: 13 June 2011

Published: 13 June 2011

\section{References}

1. van der Wal MF, Benninga MA, Hirasing RA: The prevalence of encopresis in a multicultural population. J Pediatr Gastroenterol Nutr 2005, 40:345-348.

2. de Araujo Sant'Anna AM, Calcado AC: Constipation in school-aged children at public schools in Rio de Janeiro, Brazil. J Pediatr Gastroenterol Nutr 1999, 29:190-193.

3. Yong D, Beattie RM: Normal bowel habit and prevalence of constipation in primary-school children. Ambulatory Child Health 1998, 4:277-282.

4. Liem O, Harman J, Benninga M, Kelleher K, Mousa H, Di LC: Health utilization and cost impact of childhood constipation in the United States. J Pediatr 2009, 154:258-262.

5. NICE Guidelines: Constipation in children. Internet Communication 2010 [http://www.nice.org.uk/guidance/CG99].

6. Weaver LT, Steiner $\mathrm{H}$ : The bowel habit of young children. Arch Dis Child 1984, 59:649-652.

7. Nyhan WL: Stool frequency of normal infants in the first week of life. Pediatrics 1952, 10:414-425.

8. Metaj M, Laroia N, Lawrence RA, Ryan RM: Comparison of breast- and formula-fed normal newborns in time to first stool and urine. J Perinatol 2003, 23:624-628.

9. Loening-Baucke V: Constipation in early childhood: patient characteristics, treatment, and longterm follow up. Gut 1993, 34:1400-1404

10. Rasquin A, Di LC, Forbes D, Guiraldes E, Hyams JS, Staiano A, Walker LS: Childhood functional gastrointestinal disorders: child/adolescent. Gastroenterology 2006, 130:1527-1537.

11. Benninga M, Candy DC, Catto-Smith AG, Clayden G, Loening-Baucke V, Di LC, Nurko S, Staiano A: The Paris Consensus on Childhood Constipation Terminology (PACCT) Group. J Pediatr Gastroenterol Nutr 2005, 40:273-275.

12. Aydoðdu S, Çakýr M, Yüksekkaya HA, Arýkan C, Tümgör G, Baran M, Yaðcý RV: The Turkish Journal of Pediatrics 2009, 51:146-153.

13. Loening-Baucke $\mathrm{V}$ : Prevalence rates for constipation and faecal and urinary incontinence. Arch Dis Child 2007, 92:486-489.

14. Arvola T, Ruuska T, Keranen J, Hyoty H, Salminen S, Isolauri E: Rectal bleeding in infancy: clinical, allergological, and microbiological examination. Pediatrics 2006, 117:e760-e768.

15. O'Regan S, Yazbeck S, Hamberger B, Schick E: Constipation a commonly unrecognized cause of enuresis. Am J Dis Child 1986, 140:260-261.

16. Farhat W, Bagli DJ, Capolicchio G, O'Reilly S, Merguerian PA, Khoury A, McLorie GA: The dysfunctional voiding scoring system: quantitative standardization of dysfunctional voiding symptoms in children. J Urol 2000, 164:1011-1015.
17. Koff $S A$, Wagner $T$, Jayanthi VR: The relationship among dysfunctional elimination syndromes, primary vesicoureteral reflux and urinary tract infections in children. J Urol 1998, 160:1019-1022.

18. Yazbeck S, Schick E, O'Regan S: Relevance of constipation to enuresis, urinary tract infection and reflux. A review. Eur Urol 1987, 13:318-321.

19. Misra S, Lee A, Gensel K: Chronic constipation in overweight children. JPEN J Parenter Enteral Nutr 2006, 30:81-84

20. Pashankar DS, Loening-Baucke V: Increased prevalence of obesity in children with functional constipation evaluated in an academic medical center. Pediatrics 2005, 116:e377-e380.

21. Issenman RM, Hewson S, Pirhonen D, Taylor W, Tirosh A: Are chronic digestive complaints the result of abnormal dietary patterns? Diet and digestive complaints in children at 22 and 40 months of age. Am J Dis Child 1987, 141:679-682.

22. Morris-Yates A, Talley NJ, Boyce PM, Nandurkar S, Andrews G: Evidence of a genetic contribution to functional bowel disorder. Am J Gastroenterol 1998, 93:1311-1317.

23. Di LC: Pediatric anorectal disorders. Gastroenterol Clin North Am 2001, 30:269-87, ix.

24. Schonwald A, Sherritt L, Stadtler A, Bridgemohan C: Factors associated with difficult toilet training. Pediatrics 2004, 113:1753-1757.

25. Irastorza I, Ibanez B, Delgado-Sanzonetti L, Maruri N, Vitoria JC: Cow's-milkfree diet as a therapeutic option in childhood chronic constipation. J Pediatr Gastroenterol Nutr 2010, 51:171-176.

26. El-Hodhod MA, Younis NT, Zaitoun YA, Daoud SD: Cow's milk allergy related pediatric constipation: appropriate time of milk tolerance. Pediatr Allergy Immunol 2010, 21:e407-e412.

27. lacono G, Cavataio F, Montalto G, Florena A, Tumminello M, Soresi M, Notarbartolo A, Carroccio A: Intolerance of cow's milk and chronic constipation in children. N Engl J Med 1998, 339:1100-1104.

28. Partin JC, Hamill SK, Fischel JE, Partin JS: Painful defecation and fecal soiling in children. Pediatrics 1992, 89:1007-1009.

29. Rasquin-Weber A, Hyman PE, Cucchiara S, Fleisher DR, Hyams JS, Milla PJ, Staiano A: Childhood functional gastrointestinal disorders. Gut 1999, , 45 Suppl 2: $\| 60-1168$.

30. Loening-Baucke V, Swidsinski A: Constipation as cause of acute abdominal pain in children. J Pediatr 2007, 151:666-669.

31. Afzal N, Murch S, Thirrupathy K, Berger L, Fagbemi A, Heuschkel R: Constipation with acquired megarectum in children with autism. Pediatrics 2003, 112:939-942.

32. Mellon MW, Whiteside SP, Friedrich WN: The relevance of fecal soiling as an indicator of child sexual abuse: a preliminary analysis. J Dev Behav Pediatr 2006, 27:25-32.

33. Leech SC, McHugh K, Sullivan PB: Evaluation of a method of assessing faecal loading on plain abdominal radiographs in children. Pediatr Radiol 1999, 29:255-258.

34. van den BM, Graafmans D, Nievelstein R, Beek E: Systematic assessment of constipation on plain abdominal radiographs in children. Pediatr Radiol 2006, 36:224-226.

35. Jackson CR, Lee RE, Wylie AB, Adams C, Jaffray B: Diagnostic accuracy of the Barr and Blethyn radiological scoring systems for childhood constipation assessed using colonic transit time as the gold standard. Pediatr Radiol 2009.

36. Rockney RM, McQuade WH, Days AL: The plain abdominal roentgenogram in the management of encopresis. Arch Pediatr Adolesc Med 1995, 149:623-627.

37. van den BM, Graafmans D, Nievelstein R, Beek E: Systematic assessment of constipation on plain abdominal radiographs in children. Pediatr Radiol 2006, 36:224-226.

38. Bijos A, Czerwionka-Szaflarska M, Mazur A, Romanczuk W: The usefulness of ultrasound examination of the bowel as a method of assessment of functional chronic constipation in children. Pediatr Radiol 2007, 37:1247-1252.

39. Pensabene L, Youssef NN, Griffiths JM, Di LC: Colonic manometry in children with defecatory disorders. role in diagnosis and management. Am J Gastroenterol 2003, 98:1052-1057.

40. Ghosh A, Griffiths DM: Rectal biopsy in the investigation of constipation. Arch Dis Child 1998, 79:266-268.

41. Davidson M, Bauer CH: Studies of distal colonic motility in children. IV. Achalasia of the distal rectal segment despite presence of ganglia in the myenteric plexuses of this area. Pediatrics 1958, 21:746-761. 
42. Whitlock-Morales A, McKeand C, DiFilippo M, Elitsur Y: Diagnosis and treatment of constipation in children: a survey of primary care physicians in West Virginia. W V Med J 2007, 103:14-16.

43. Borowitz SM, Cox DJ, Kovatchev B, Ritterband LM, Sheen J, Sutphen J: Treatment of childhood constipation by primary care physicians: efficacy and predictors of outcome. Pediatrics 2005, 115:873-877.

44. Boyt MA: Teachers' knowledge of normal and abnormal elimination patterns in elementary school children. J Sch Nurs 2005, 21:346-349.

45. Hillemeier C: An overview of the effects of dietary fiber on gastrointestinal transit. Pediatrics 1995, 96:997-999.

46. Morais MB, Vitolo MR, Aguirre AN, Fagundes-Neto U: Measurement of low dietary fiber intake as a risk factor for chronic constipation in children. $J$ Pediatr Gastroenterol Nutr 1999, 29:132-135.

47. Guimaraes EV, Goulart EM, Penna FJ: Dietary fiber intake, stool frequency and colonic transit time in chronic functional constipation in children. Braz J Med Biol Res 2001, 34:1147-1153.

48. du TG, Meyer R, Shah N, Heine RG, Thomson MA, Lack G, Fox AT: Identifying and managing cow's milk protein allergy. Arch Dis Child Educ Pract Ed 2010, 95:134-144.

49. Jennings A, Davies GJ, Costarelli V, Dettmar PW: Dietary fibre, fluids and physical activity in relation to constipation symptoms in pre-adolescent children. J Child Health Care 2009, 13:116-127.

50. Phillips B, Ball C, Sackett D, Badenoch D, Straus S, Haynes B, Dawes M: Levels of Evidence: Oxford Centre for Evidence-based Medicine. Centre for Evidence Based Medicine, Department of Primary Care, Old Road Centre, Oxford 2009

51. Voskuijl W, de LF, Verwijs W, Hogeman P, Heijmans J, Makel W, Taminiau J, Benninga M: PEG 3350 (Transipeg) versus lactulose in the treatment of childhood functional constipation: a double blind, randomised, controlled, multicentre trial. Gut 2004, 53:1590-1594

52. van GR, Benninga MA, Blommaart PJ, van der Plas RN, Boeckxstaens GE, Buller HA, Taminiau JA: Lack of benefit of laxatives as adjunctive therapy for functional nonretentive fecal soiling in children. J Pediatr 2000, 137:808-813.

53. Perkin JM: Constipation in childhood: a controlled comparison between lactulose and standardized senna. Curr Med Res Opin 1977, 4:540-543.

54. Dupont C, Leluyer B, Maamri N, Morali A, Joye JP, Fiorini JM, Abdelatif A, Baranes C, Benoit S, Benssoussan A, Boussioux JL, Boyer P, Brunet E, Delorme J, Francois-Cecchin S, Gottrand F, Grassart M, Hadji S, Kalidjian A, Languepin J, Leissler C, Lejay D, Livon D, Lopez JP, Mougenot JF, Risse JC, Rizk C, Roumaneix D, Schirrer J, Thoron B, Kalach N: Double-blind randomized evaluation of clinical and biological tolerance of polyethylene glycol 4000 versus lactulose in constipated children. $J$ Pediatr Gastroenterol Nutr 2005, 41:625-633.

55. Keuzenkamp-Jansen CW, Fijnvandraat CJ, Kneepkens CM, Douwes AC Diagnostic dilemmas and results of treatment for chronic constipation. Arch Dis Child 1996, 75:36-41.

56. Connolly P, Hughes IW, Ryan G: Comparison of "Duphalac" and "irritant" laxatives during and after treatment of chronic constipation: a preliminary study. Curr Med Res Opin 1974, 2:620-625.

57. Thomson MA, Jenkins HR, Bisset WM, Heuschkel R, Kalra DS, Green MR, Wilson DC, Geraint M: Polyethylene glycol 3350 plus electrolytes for chronic constipation in children: a double blind, placebo controlled, crossover study. Arch Dis Child 2007, 92:996-1000.

58. Candy DC, Edwards D, Geraint M: Treatment of faecal impaction with polyethelene glycol plus electrolytes (PGE + E) followed by a doubleblind comparison of PEG + E versus lactulose as maintenance therapy. J Pediatr Gastroenterol Nutr 2006, 43:65-70.

59. Gremse DA, Hixon J, Crutchfield A: Comparison of polyethylene glycol 3350 and lactulose for treatment of chronic constipation in children. Clin Pediatr (Phila) 2002, 41:225-229.

60. Loening-Baucke V, Pashankar DS: A randomized, prospective, comparison study of polyethylene glycol 3350 without electrolytes and milk of magnesia for children with constipation and fecal incontinence. Pediatrics 2006, 118:528-535.

61. Youssef NN, Peters JM, Henderson W, Shultz-Peters S, Lockhart DK, Di LC: Dose response of PEG 3350 for the treatment of childhood fecal impaction. J Pediatr 2002, 141:410-414.

62. Michail S, Gendy E, Preud'Homme D, Mezoff A: Polyethylene glycol for constipation in children younger than eighteen months old. J Pediatr Gastroenterol Nutr 2004, 39:197-199.
63. Ingebo KB, Heyman MB: Polyethylene glycol-electrolyte solution for intestinal clearance in children with refractory encopresis. A safe and effective therapeutic program. Am J Dis Child 1988, 142:340-342.

64. Miller MK, Dowd MD, Fraker M: Emergency department management and short-term outcome of children with constipation. Pediatr Emerg Care 2007, 23:1-4.

65. Pashankar DS, Bishop WP, Loening-Baucke V: Long-term efficacy of polyethylene glycol 3350 for the treatment of chronic constipation in children with and without encopresis. Clin Pediatr (Phila) 2003, 42:815-819.

66. Pashankar DS, Loening-Baucke V, Bishop WP: Safety of polyethylene glycol 3350 for the treatment of chronic constipation in children. Arch Pediatr Adolesc Med 2003, 157:661-664

67. Pashankar DS, Bishop WP: Efficacy and optimal dose of daily polyethylene glycol 3350 for treatment of constipation and encopresis in children. $J$ Pediatr 2001, 139:428-432.

68. Erickson BA, Austin JC, Cooper CS, Boyt MA: Polyethylene glycol 3350 for constipation in children with dysfunctional elimination. J Urol 2003, 170:1518-1520.

69. Hanson S, Bansal N: The clinical effectiveness of Movicol in children with severe constipation: an outcome audit. Paediatr Nurs 2006, 18:24-28.

70. Loening-Baucke V, Krishna R, Pashankar DS: Polyethylene glycol 3350 without electrolytes for the treatment of functional constipation in infants and toddlers. J Pediatr Gastroenterol Nutr 2004, 39:536-539.

71. Berg I, Forsythe I, Holt P, Watts J: A controlled trial of 'Senokot' in faecal soiling treated by behavioural methods. J Child Psychol Psychiatry 1983, 24:543-549.

72. Sondheimer JM, Gervaise EP: Lubricant versus laxative in the treatment of chronic functional constipation of children: a comparative study. J Pediatr Gastroenterol Nutr 1982, 1:223-226.

73. Bellomo-Brandao MA, Collares EF, da-Costa-Pinto EA: Use of erythromycin for the treatment of severe chronic constipation in children. Brazilian Journal of Medical \& Biological Research 2003, 36(10):1391-1396.

74. Gleghorn EE, Heyman MB, Rudolph CD: No-enema therapy for idiopathic constipation and encopresis. Clinical Pediatrics 1991, 30(12):669-672.

75. Tolia V, Lin CH, Elitsur Y: A prospective randomized study with mineral oil and oral lavage solution for treatment of faecal impaction in children. Aliment Pharmacol Ther 1993, 7:523-529.

76. van GR, Reitsma JB, Buller HA, van Wijk MP, Taminiau JA, Benninga MA: Childhood constipation: longitudinal follow-up beyond puberty. Gastroenterology 2003, 125:357-363.

77. Elshimy N, Gallagher B, West D, Stringer MD, Puntis JW: Outcome in children under 5 years of age with constipation: a prospective follow-up study. Int J Clin Pract 2000, 54:25-27.

78. Loening-Baucke V: Chronic constipation in children. Gastroenterology 1993, 105:1557-1564.

doi:10.1186/1824-7288-37-28

Cite this article as: Afzal et al: Constipation in children. Italian Journal of Pediatrics 2011 37:28.

\section{Submit your next manuscript to BioMed Central and take full advantage of:}

- Convenient online submission

- Thorough peer review

- No space constraints or color figure charges

- Immediate publication on acceptance

- Inclusion in PubMed, CAS, Scopus and Google Scholar

- Research which is freely available for redistribution

Submit your manuscript at www.biomedcentral.com/submit
C Biomed Central 